\title{
Investigating the impacts of climate change and human activities on hydrological drought: A Case Study on Nenjiang River Basin in China
}

\author{
Baohui Men ${ }^{1}$, Meitong Jiang ${ }^{1}$, and Wei Tian ${ }^{2}$ \\ ${ }^{1}$ North China Electric Power University \\ ${ }^{2}$ Institute of Geographic Sciences and Natural Resources Research Chinese Academy of \\ Sciences
}

October 5, 2020

\begin{abstract}
Hydrological drought is one of the most destructive natural disasters, and it has large negative impacts on agriculture, water resources, and human life. Characteristics of hydrological drought are generally affected by climate change and human activities. Assessing the impacts of climate change and human activities on hydrological drought is important for water resources management. This study aims to evaluate the impacts for the Nenjiang River Basin in Northeast China, where the only large controlled water conservancy project, the Nierji Reservoir, was officially completed in December 2006. Firstly, two methods, namely hydrological simulations based on the SWAT and the Budyko framework, were used to evaluate the impacts on runoff at four stations after the construction of the reservoir. Both methods show that human activities contribute the most to the runoff changes at the four stations. Among the human activities, returning farmland to forests was the main factor affecting runoff changes in the upstream of the Nierji Reservoir, while reservoir construction was the main factor affecting runoff in the downstream. Then the Standardized Runoff Index and run theory were used to identify the hydrological drought, and the simulated-observed method was used to evaluate the impacts on the hydrological drought. For long-term droughts, the construction of reservoirs has reduced the monthly average intensity and the peak value of drought for the downstream of the reservoir. For short-term droughts, the construction of reservoirs has reduced the intensity and duration of drought for the downstream of the reservoir. The results of the study may help relevant departments to rationally allocate, optimize, and protect the limited water resources of the Nenjiang River Basin. The results of the study may help relevant departments to rationally allocate, optimize, and protect the limited water resources of the Nenjiang River Basin.
\end{abstract}

Investigating the impacts of climate change and human activities on hydrological drought: A Case Study on Nenjiang River Basin in China

Running Title: ANALYSIS OF HYDROLOGICAL DROUGHT IN NENJIANG RIVER BASIN

Baohui Men ${ }^{1}$, Meitong Jiang ${ }^{1}$, Wei Tian ${ }^{2,3^{*}}$

${ }^{1}$ School of Water Resources and Hydropower Engineering, North China Electric Power University, Beijing 102206, China

${ }^{2}$ Key Laboratory of Water Cycle \& Related Land Surface Process, Institute of Geographic Sciences and Natural Resources Research, Chinese Academy of Sciences, 100101 Beijing, China

${ }^{3}$ University of Chinese Academy of Sciences, Beijing, China.

* Corresponding author: Wei Tian, Email: tianweiBT@163.com 
Acknowledgements:

The authors acknowledge the funds supported by National Key R\& D Program of China (Grant No. 2016YFC0401406), and the Famous Teachers Cultivation planning for Teaching of North China Electric Power University (the Fourth Period).

\section{Hosted file}

Abstract.pdf available at https://authorea.com/users/364128/articles/484652-investigatingthe-impacts-of-climate-change-and-human-activities-on-hydrological-drought-a-case-studyon-nenjiang-river-basin-in-china

\section{Hosted file}

main text file.pdf available at https://authorea.com/users/364128/articles/484652investigating-the-impacts-of-climate-change-and-human-activities-on-hydrologicaldrought-a-case-study-on-nenjiang-river-basin-in-china

\section{Hosted file}

Figure legends.pdf available at https://authorea.com/users/364128/articles/484652investigating-the-impacts-of-climate-change-and-human-activities-on-hydrologicaldrought-a-case-study-on-nenjiang-river-basin-in-china

\section{Hosted file}

Table.pdf available at https://authorea.com/users/364128/articles/484652-investigating-theimpacts-of-climate-change-and-human-activities-on-hydrological-drought-a-case-study-onnenjiang-river-basin-in-china 